\title{
THE WEAKNESSES OF ALTERNATIVE INSTITUTIONS FOR DISPUTE RESOLUTION IN FINANCIAL SERVICES SECTOR
}

\author{
Theresia Anita Christiani \\ Universitas Atma Jaya Yogyakarta, Indonesia \\ anita.christiani@uajy.ac.id \\ Chryssantus Kastowo \\ Universitas Atma Jaya Yogyakarta, Indonesia \\ maskatho@gmail.com
}

\begin{abstract}
There are weaknesses in the Financial Services Authority issued POJK No. 61/POJK/2020 concerning Alternative Dispute Resolution in the financial services sector. It hampered the objectives of the regulation. A concept proposal is needed to overcome the existing weaknesses. This research uses normative juridical analysis. This research dose on the laws and regulations that apply in Indonesia relating to the settlement of disputes in the financial services sector. This study finds a proposed concept to overcome the weaknesses of Alternative Dispute Resolution in the financial services sector. The proposed idea empowers legal culture, legal substance, and legal culture as legal system theory. This research is limited to study based on secondary data, so there is no primary data.
\end{abstract}

Keywords: Dispute; Financial; Legal; Juridical; Weakness.

\section{A. INTRODUCTION}

The financial services sector in Indonesia plays a significant role in supporting the movement of the financial system. Public trust in the financial services sector is an essential key for sustainability, and the number of disputes that occur in the financial services sector will decrease public trust. Therefore, in 2020 the Financial Services Authority issued Regulation No. 61/POJK.07/2020 concerning Alternative Institutions for Dispute Resolution in the Financial Services Sector. An alternative institution for dispute resolution of the financial services sector makes settlement disputes integrated into one such institution. In practice in Indonesia, some institutions have the authority to handle conflicts that arise. These institutions are judicial institutions, Consumer Dispute Resolution Bodies, and Alternative Institutions for Dispute Resolution in the financial services sector. The judiciary is an institution conventionally given the authority to resolve disputes in society. For example, The Civil Court is a litigation institution that handles consumer issues and submitted actors in the financial service sector. In addition, other institutions are better known in the local community, namely the Consumer Dispute Resolution Agency, in 
resolving consumer disputes based on Act No. 8 of 1999 on Consumer Protection.

Based on the juridical facts above, it is essential to find a legal concept to overcome the alternative institutions' weaknesses for Dispute Resolution in the Financial Services Sector. It is so that the birth of this institution can achieve its goals. This study aims to propose a concept that can be a proposed solution to the weaknesses of alternative institutions for dispute resolution in the financial services sector. Previous research related to the resolution of business disputes was carried out by Plevry, who explained the use of ADR. ${ }^{1}$ and ODR for EU consumers by comparing them with traditional dispute resolution ${ }^{2}$. Subsequent research was carried out by discussing adjudication as a settlement method of payment transactions in the construction industry in Ireland. The study aims to find out the impact of related regulations. ${ }^{3}$ Then Noone, M., \& Ojelabi, L, also conducted research related to various types of alternative disputes offered in Australia and whether the purpose of establishing this mechanism to obtain justice can be achieved or not. ${ }^{4}$. Another research conducted in Indonesia states that Alternative Dispute Resolution is also found in Islamic banking practices. ${ }^{5}$ Alternative dispute resolution is like Mediation in Indonesia, especially in dealing with civil matters. But other research ${ }^{6}$ has found that mediation ${ }^{7}$ is needed in resolving criminal disputes ${ }^{8}$. This research is different from this research because this research examines the weaknesses in the financial services sector dispute resolution alternative institutions that have just emerged in 2020. The novelty of this research can also be seen from the proposed concept of solutions to the weaknesses in implementation and Alternative Institutions for Dispute Resolution in the Financial Services Sector in Indonesia. Formulation problem statement. How do the proposed concepts address the shortcomings of alternative institutions for dispute resolution in the financial services sector in

1 Kirimi, H. \& Wanjohi, J., Factors Influencing The Use Of Alternative Dispute Resolution In Construction Projects: Case of Imenti North Sub County, Meru County. International Academic Journal of Information Sciences and Project Management, Vol.3 No.4, page. 2019, 572-602

2 Plevri A. Alternative Dispute Resolution (ADR) \& Online Dispute Resolution (ODR) for EU Consumers: The European and Cypriot Framework. In: Synodinou TE., Jougleux P., Markou C., Prastitou T. (eds) EU Internet Law in the Digital Era. Springer, Cham. 2020,

3 Peter O'Malley, 'The Irish 'Construction Contracts Act 2013': Adjudication - What Has Happened and Where Next,' 86, Arbitration: The International Journal of Arbitration, Mediation and Dispute Management, Issue 2, 2020, page. 133-156,

4 Noone, M., \& Ojelabi, L. Alternative dispute resolution and access to justice in Australia, International Journal of Law in Context, Vol.16 No.2, 2020, page. 108-127,

5 Puneri, A., Dispute Resolutions Mechanisms for Islamic Banks In Indonesia, International Journal of Islamic Economics and Finance (IJIEF), 4(SI), 2021, page.153-180,

6 Soewondo, D, Mediating Civil Disputes Through Local Wisdom, Jurnal Pembaharuan Hukum, Unisulla Vol 7 No 1, 2020,

7 Anggraeni A., Penal Mediation as Alternative Dispute Resolution: A Criminal Law Reform in Indonesia, Journal of Law and Legal Reform, Vol. 1 No. 2, 2020. page.369-380

8 Ratri Novita Erdianti, Wasis Suprayitno, Sholahuddin Al-Fatih. Penal Mediation as an Alternative Dispute Resolution for Indonesian Criminal Code, Jurnal Wacana Hukum, Vol. 26 No. 1, 2021, 
Indonesia? The Research objective is to finds a concept to overcome the weaknesses of alternative institutions for dispute resolution in the financial services sector.

\section{B. RESEARCH METHODS}

This research uses normative ${ }^{9}$ juridical research ${ }^{10}$. This research focuses on the laws and regulations ${ }^{11}$ that apply in Indonesia relating to the settlement of disputes that occur in the financial services sector. This study uses a statutory approach ${ }^{12}$ and a conceptual approach. These two approaches analyze the proposed concepts to overcome weaknesses in this alternative institution to settle the financial services sector. Secondary data is the leading data in this study which consists of primary and secondary legal materials. The primary legal materials used are Act No. 21 of 2011 concerning the Financial Services Authority, Act No. 8 of 1999 Concerning Consumer Protection, Government Regulation No. 4 of 2019, Regulation of the Financial Services Authority No. 61/POJK.07/2020 concerning Alternative Institutions for Dispute Resolution Financial Services Sector. Articles from various international journals, books, dictionaries are secondary legal materials used in this research. Technically analyzing data is used qualitatively. ${ }^{13}$ All secondary data were collected, separated and described, and then analyzed. Describing and analyzing data was carried out using a conceptual approach ${ }^{14}$ laws and regulations a historical approach. Conclusions are drawn by using a deductive thought process. ${ }^{15}$

\section{RESULT AND DISCUSSION}

\section{Dispute Resolution Institutions in the field of Business}

Activities in the economic sector are the fields that can most influence and lead to movements in the socio-cultural, political, legal, and security fields. The financial services sector is a field that is involved in these economic activities. The diversity of interests of economic actors in their activities often creates disputes. Disputes that occur need to be

9 Poesche, J. A Poisoned Chalice: Homophobia And Codes Of Conduct, International Journal of Law and Management, Vol. 62 No. 6, 2020, page. 557-576

10 Kharisma, D.B. Urgency of financial technology (Fintech) laws in Indonesia," International Journal of Law and Management, Vol. 63 No. 3, 2021. https://doi.org/10.1108/IJLMA-082020-0233, p. 320-331,

11 Hermanto, A. and Narindro, L., "New geothermal law and its implications for geothermal development in Indonesia," International Journal of Law and Management, Vol. 61 No. 1, 2019, https://doi.org/10.1108/IJLMA-10-2017-0248, p. 2-16.

12 Malsukhum, Voraphol. Influence of the Legal Cultures on Jurisdictional Fact. 10.1007/978981-16-1267-1_4. 2021.

13 Sethi, D. and Arya, V., "Legal implications are governing medical negligence in India: creating awareness through a six-dimensional framework of effective communication," International Journal of Law and Management, Vol. 62 No. 5, 2021, https://doi.org/10.1108/IJLMA-06-2018-0123, p. 417-425.

14 Fence M., Novendri M. Mellisa T, and Ahmad, Indonesian Constitutional Interpretation: Constitutional Court Versus the People's Consultative Assembly, Journal Of Legal Ethical and Regulatory Issues, Vol 24 Issue 6. 2021,

15 Gass, Robert \& Seiter, John. Deductive Reasoning. 2021, 
resolved so that they do not become obstacles to the sustainability of economic activities that can affect all aspects of society.

Methods of dispute resolution can be divided into ways using litigation and non-litigation. The litigation method is a way of resolving disputes through the judiciary. Meanwhile, the non-litigation process is often referred to as the dispute resolution alternative. These two methods essentially have the same goal, namely to get justice for the parties. ${ }^{16}$

In practice, there are institutions formed to solve problems in the financial services sector that cause disputes. Parties to the conflict can be between financial services institutions and the public or between institutions in the financial services sector and parties outside the financial services sector. The institutions provided are the judiciary, the Consumer Dispute Resolution Agency, the National Consumer Protection Agency, and the Alternative Institution for Dispute Resolution in the financial services sector.

A judicial institution is an institution that can be included in the category of litigation institutions. An institution with a litigation paradigm is an institution that uses a behavioral approach or a culture of justice (distributive) in dispute resolution through a system of resistance in Court and using coercion. It produces a win-lose solution decision. ${ }^{17} \mathrm{~A}$ win-lose solution can be defined as losing and winning parties in the final result of the judicial body's decision. From the aspect of economic actors, the result of a win-lose solution can mean that there are parties who lose and win due to the findings of the judiciary chosen. Of course, the litigation paradigm with the final win-lose solution is the outcome that is not sure to benefit, especially to the losing party. The defeat in a specific case will impact economic actors who prioritize public trust in their activities. Other conventional weaknesses are found in resolving disputes through this litigation path: poor judges' competence, long time for final decision making, and weak execution of civil court decisions. Weaknesses of weaknesses in dispute resolution in judicial institutions also occur in other countries, as stated by Ash Gurbuz Usluel. ${ }^{18}$. The weakness of efforts to resolve disputes through the judiciary will impact decreasing public trust in banking institutions.

The Consumer Dispute Resolution Institution is a dispute resolution institution based on the Consumer Protection Act No. 8 of 1999 and the Decree of the Minister of Industry and Trade No. 350/MPP/KEP/12/2001 concerning the Implementation of Duties and Authorities of Consumer Dispute Resolution Bodies. Consumers and business actors who have disputes hold discussions in resolving their disputes. If the parties do not

16 Jacqueline Nolan-Haley, International Dispute Resolution and Access to Justice: Comparative Law Perspectives, J. Disp. Resol. 2020,

17 Adi Sulistiono, Tantangan Memberdayakan LAPS (OJK), Sosialisasi LAPS SJK-OJK, 6 May 2021,

18 Ash Gurbuz Usluel, Mandatory or Voluntary Mediation? Recent Turkish Mediation Legislation and a Comparative Analysis with the EU's Mediation Framework, J. Disp. Resol. 2020, 
find a resolution, they can submit their dispute through this Consumer Dispute Resolution Agency. If the Consumer Dispute Resolution Board cannot resolve the conflict, they can bring their dispute to Court. Meanwhile, the National Consumer Protection Agency is formed based on Act No. 8 of 1999 and Regulation No. 4 of 2019.

Alternative Institution for Financial Services Sector Dispute Resolution was formed based on Financial Services Authority Regulation No. 61/POJK.07/2020 concerning Alternative Institutions for Financial Services Sector Dispute Resolution. Financial Services Sector Dispute Resolution at POJK No. 1/POJK.07/2013 Regarding Consumer Protection, the settlement of disputes in the financial services sector is carried out in two stages. First, the stage through internal dispute resolution, Second, the external dispute resolution stage. Internal dispute resolution disputes between consumers and business actors in the financial services sector by making an agreement and settlement between the two parties. Suppose the first stage cannot produce a settlement agreed upon by both parties. In that case, consumers can submit their dispute resolution through an Alternative Dispute Resolution Agency registered and determined by the Financial Services Authority. This institution consists of various institutions according to the type of financial services sector. With the Financial Services Authority Regulation No.61/POJK.07/2020, alternative dispute resolution institutions are integrated with each type of financial service sector into one institution with the task and authority to resolve consumer disputes in all financial services sectors.

\section{The Strengths and Weaknesses of the Alternative Institutions for Financial Services Sector Dispute Resolution}

This alternative dispute resolution institution based on POJK No.61/POJK.07/2020 concerning Alternative Institutions for Dispute Resolution in the Financial Services Sector has advantages over other dispute resolution institutions. First, these advantages include allowing the parties to choose an alternative institution outside the Court that can provide a sense of justice for the parties. ${ }^{19}$. With the existence of this institution, there is an institutional integration for handling disputes outside the judiciary that the parties can choose. Second, the approach used is an approach that seeks agreement and deliberation on the best solution for both parties. Third, a solution that is characterized by a winwin solution. This character will be better because, in the business world, consumer confidence is strongly influenced by decisions that are detrimental to a business actor, such as those in dispute resolution with a win-lose solution character. Problem resolution through alternative dispute resolution in the financial services sector is effective and efficient compared to dispute resolution in Court. The nature of the dispute resolution is expected to support business actors and maintain the sustainability of economic activity in the financial services sector.

19 Nasibli, Firuza., Advantages Of Mediation Over The Court-Based Litigation Process, Juridical Sciences and Education, 62, 2020, page. 146-151 
Alternative Institutions for Dispute Resolution in the financial services sector have weaknesses; First, several alternative dispute resolution options between consumers and actors in the financial services sector already exist and are running well and are also better known by the public. In settlement of disputes through court institutions, there is a simple lawsuit. In practice, dispute resolution through litigation with a simple case has been proven effective in resolving disputes between consumers and actors in the financial services sector. Second, a Consumer Dispute Resolution Agency is based on a higher provision, namely Act No. 8 of 1999 concerning Consumer Protection. Consumer Dispute Settlement Agency is also widely known in the country. Third. Even though the implementation of the agreement for Arbitration and mediation can get executive power from the Court, the guarantee for the performance of the decision is still debatable.

\section{The Concept to Overcome the Weaknesses of Alternative Dispute Resolution in the Financial Services Sector from Legal System Theory.}

Economic activity has the essence of bringing together the interests of the various parties and lead to disputes. There are various alternative institutions provided. ${ }^{20}$ To resolve their disputes. For business actors, litigation settlement efforts will require high costs and cause unwanted consequences. ${ }^{21}$

In the theory of the legal system proposed by Friedman, legal culture is underestimated as behavior in society, which is one of the elements of the legal system. ${ }^{22}$ Among other elements, namely legal substance and legal structures. ${ }^{23}$ Legal culture reflects behavior and habits that are considered good, not written, but supporting the community. A set of good faith is one of the principles known in our Law. In the Law of the agreement, the principle of good faith is known, which means that the parties agreed upon have consequences for compliance with the agreement's contents. The principle of good faith works in the implementation of the contract. Furthermore, Friedman also provides thoughts on understanding empirical information about the extent to which government structures and social forces outside the legal system affect the creation of laws and legal norms. ${ }^{24}$ Legal structure appoints

20 Radiant, Ratri Novita and Suprayitno, Wasis and Al-Fatih, Sholahudd, Penal Mediation as an Alternative Dispute Resolution for Indonesian Criminal Code, Wacana Hukum Jurnal Fakultas Hukum Universitas Slamet Riyadi, 2020, page. 39-48.

21 Macaulay S, Non-contractual Relations in Business: A Preliminary Study, In: Campbell D. (eds) Stewart Macaulay: Selected Works. Law and Philosophy Library, vol 133. Cham, Springer, 1963

22 Mauk, David \& Tønnessen, Alf \& Oakland, John, The Legal System, 2021,

23 Saksonov, Vladyslav \& Romashchenko, Kostyantyn. Legal Structure "Law Of Trusts" In The Civil Legislation Of Ukraine, Naukovyy Visnyk Dnipropetrovs'kogo Derzhavnogo Universytetu Vnutrishnikh Sprav. 2020, page. 120-126.

24 Ari Zuckerbrot, Book Review: Impact: How Law Affects Behavior, by Lawrence M. Friedman, 2019 55-3, Osgoode Hall Law Journal, 846, 2019 
institutions and law enforcement. Legal substance means the rules, norms, and behavior patterns of the parties implementing the regulations. These three elements must constitute a legal system that can be a social control tool and solve problems in society. ${ }^{25}$

The results of the study indicate that there are weaknesses in alternative institutions for dispute resolution in the financial services sector as the implementation of Financial Services Authority Regulation No.61/POJK.07/2020, as follows:

First, Alternative institutions for dispute resolution in the financial services sector are based on the provisions of Financial Services Authority Regulation No. 61/POJK.07/2020. While in practice, there is already an Institution called the Consumer Dispute Resolution Institution, which was born based on the Consumer Protection Act. The consumer dispute settlement institution exists, which also has the authority to resolve disputes between consumers and financial institutions, especially banking institutions. This fact is a legal fact that will hinder the development of alternative institutions for dispute resolution in the financial services sector. This weakness is a weakness from the aspect of legal substance. The issue of legal substance has the consequence that both the Consumer Dispute Settlement Agency and the Financial Services Sector Alternative Dispute Resolution Institution have the authority to resolve consumer disputes in the activities of the financial services sector. Requiring financial service actors to use alternative financial services institutions are set out in the form of regulations by the financial services authority.

Second, Article 3 of Act No. 30 of 1999 concerning Arbitration and Alternative Dispute Resolution stipulates that the District Court is not authorized to adjudicate the parties' disputes to which the arbitration agreement has bound. Article 11 specifies that the existence of a written arbitration agreement nullifies the parties' rights to submit a dispute resolution or difference of opinion contained in the contract to the District Court. The Indonesia District Court is obliged to refuse and will not intervene in a dispute resolution that has been determined through Arbitration, except in some instances stipulated in this Law. The provisions of Article 3 and Article 11 of Act No. 30 of 1999 mean that if an arbitration agreement binds the parties, the District Court may not try and negate the parties' rights to submit a dispute to the District Court. Threesome instances are also obliged to refuse. In practice, these provisions often conflict with Article 10, paragraph 1 of Act No. 48 of 2009 concerning Judicial Power. It shows the weakness of implementing the Alternative Dispute Resolution in Arbitration from substance and structure. The matter of substance and structure can be overcome with a shared understanding of law enforcement (judges) in respecting the choice of dispute resolution outside the courts of the parties.

Third, only 10 percent of civil decisions that are "incracht" can be

25 Lawrence M.Fridman and Grant M.H, What is Legal System, Oxford Scholarship Online, 2017. 
implemented. This situation shows that the arbitration award or mediation agreement also can be hampered by the implementation of the decision. So that the alternative dispute resolution is only used as a mechanism to postpone the obligations that must be carried out. This situation shows that culture law is not ready to implement a win-win solution for problems in society. Culture law can be overcome by increasing public awareness of agreements in good faith and prioritizing win-win dispute resolution.

The description above can be described as The concept to overcome the weaknesses of Alternative Institutions for dispute resolution in the financial services sector. The proposed concept is based on Friedman's Legal System theory.

Figure 1

Concept to overcome the weaknesses of Alternative Institutions for Dispute Resolution in the Financial Services Sector based on Legal System Theory of L. Friedman

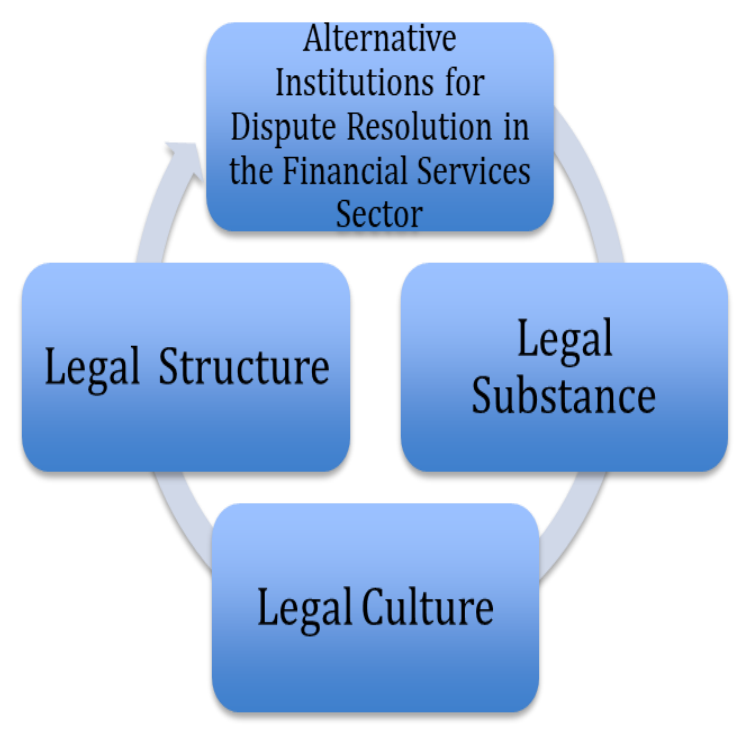

The figure shows that the weaknesses contained in alternative institutions for resolving disputes in the financial services sector can be overcome by using Friedman's theory. Friedman's theory analyses the weaknesses of alternative institutions for dispute resolution in the financial services sector and overcomes these weaknesses. At the same time, the weakness of alternative institutions for resolving disputes in the financial services sector can be seen from the aspect of the existence of dualism in institutional arrangements (legal substance), from the element of the judges' unequal interpretation of the provisions of Articles 3 and 11 of Act No. 30 of 1999 and the lack of optimal will and good faith of the community (legal culture) to implement the decisions of alternative institutions for dispute resolution in the financial services sector. Based on this, the resulting legal concept is based on the legal system's theory. First, the Consumer Dispute Settlement Agency's existence as an 
institution with a more substantial legal basis can be overcome by requiring financial service actors to use Alternative Financial Services Institutions. It is stated in the form of regulation by the Financial Services Authority (legal substance). Second, that the weakness of the dualism aspect of institutional arrangements (legal substance). The judge must reject the dispute that the Arbitration institution has decided (legal structure). The judge's attitude will overcome the weakness that comes from the dualism of regulations (legal substance). Third, the flaw stems from the community's not yet optimal will and good faith (culture). The issue of legal culture can be overcome by increasing public awareness to implement agreements in good faith and prioritizing win-win solution dispute resolution.

\section{CONCLUSION}

There are weaknesses to the Existence of Alternative Financial Services Sector Dispute Resolution Institutions. The Legal System Theory is used to analyze the weaknesses of the Alternative Financial Services Sector Dispute Resolution Institutions. Legal System Theory is also used to find concepts in overcoming the weaknesses of Alternative Dispute Resolution Institutions in the Financial Services Sector. The weakness of the Substance Legal aspect can be overcome by legal substance. The legal structure's weakness can be overcome by increasing the equality of judges' understanding (legal structure). The weakness of legal culture can be overcome by increasing public awareness to carry out agreements in good faith and prioritizing win-win dispute resolution.

\section{E. ACKNOWLEDGMENT}

Thank you to Universitas Atma Jaya Yogyakarta for providing research funds and publication fees.

\section{Books:}

\section{BIBLIOGRAPHY}

Adi Sulistiono , 2021, Tantangan Memberdayakan LAPS (OJK), Sosialisasi LAPS SJK-OJK, 6 May 2021;

Gass, Robert \& Seiter, John., 2019, Deductive Reasoning;

Mauk, David \& Tønnessen, Alf \& Oakland, John, 2021, The Legal System;

Malsukhum, Voraphol, 2021, Influence of the Legal Cultures on Jurisdictional;

\section{Journals:}

Ari Zuckerbrot, Book Review: Impact: How Law Affects Behavior, Lawrence M. Friedman, 2019 55-3 Osgoode Hall Law Journal 846, 2019;

Ash Gurbuz Usluel, Mandatory or Voluntary Mediation? Recent Turkish Mediation Legislation and a Comparative Analysis with the EU's Mediation Framework, 2020; 
Anggraeni A., Penal Mediation as Alternative Dispute Resolution: A Criminal Law Reform in Indonesia, Journal of Law and Legal Reform, Vol. 1 No.2, 2020;

Friedman,_L The Legal System A Social Science Perspective, The Russel Sage Foundation, New York, 1975;

Friedman L, and Grant M.H, What is Legal System, Oxford Scholarship Online, 2017;

Fence M., Novendri M. Mellisa T, and Ahmad, 2021, Indonesian Constitutional Interpretation: Constitutional Court Versus the People's Consultative Assembly, Journal Of Legal Ethical and Regulatory Issues, Vol 24 Issue 6, 2021;

Hermanto, A. and Narindro, L.,_- New geothermal law and its implications for geothermal development in Indonesia, International Journal of Law and Management, Vol. 61 No. 1, 2019;

Jacqueline Nolan-Haley, 2020. International Dispute Resolution and Access to Justice: Comparative Law Perspectives, 2020 J. Disp. Resol. Available;

Kirimi, H. \& Wanjohi, J., Factors influencing the use of alternative dispute resolution in construction projects: Case of Imenti North Sub County, Meru County, International Academic Journal of Information Sciences and Project Management, Vol.3 No.4, 2019;

Kharisma, D.B. Urgency of financial technology (Fintech) laws in Indonesia, International Journal of Law and Management, Vol. 63 No. 3, 2021;

Macaulay S., Non-contractual Relations in Business: A Preliminary Study. In: Campbell D. (eds) Stewart Macaulay: Selected Works. Law and Philosophy Library, Vol 133. Springer, Cham, 1963;

Noone, M., \& Ojelabi, L., Alternative dispute resolution and access to justice in Australia. International Journal of Law in Context, Vol. 16 No. 2, 2020;

Nasibli, Firuza, Advantages of Mediation Over The Court-Based Litigation Process, Juridical Sciences and Education, 62, 2020;

Plevri A., Alternative Dispute Resolution (ADR) \& Online Dispute Resolution (ODR) for EU Consumers: The European and Cypriot Framework. In: Synodinou TE., Jougleux P., Markou C., Prastitou T. (eds) EU Internet Law in the Digital Era. Springer, Cham, 2020;

Peter O'Malley, The Irish Construction Contracts Act 2013: Adjudication - What Has Happened and Where Next', 86, Arbitration: The International Journal of Arbitration, Mediation and Dispute Management, Issue 2, 2020; 
Puneri, A., Dispute Resolutions Mechanisms for Islamic Banks in Indonesia. International Journal of Islamic Economics and Finance (IJIEF), 4 (SI), 2021;

Porsche, J. A Poisoned Chalice: Homophobia And Codes Of Conduct, International Journal of Law and Management, Vol. 62 No. 6, 2020;

Radiant, Ratri Novita and Suprayitno, Wasis and Al-Fatih, Sholahuddin, Penal Mediation as an Alternative Dispute Resolution for Indonesian Criminal Code. Wacana Hukum, Jurnal Fakultas Hukum Universitas Slamet Riyadi, Vol. 26 No. 1, 2020;

Soewondo, D, Mediating Civil Disputes Through Local Wisdom, Jurnal Pembaharuan Hukum, Unisulla, Vol. 7 No. 1, 2020;

Saksonov, Vladyslav \& Romashchenko, Kostyantyn, Legal structure "law of trusts" in the civil legislation of Ukraine. Naukovyy Visnyk Dnipropetrovs'kogo Derzhavnogo Universytetu Vnutrishnikh Sprav, 2020;

Sethi, D. and Arya, V., Legal implications governing medical negligence in India: creating awareness through six-dimensional framework of effective communication, International Journal of Law and Management, Vol. 62 No. 5, 2020. 